\title{
Exploration in the Difficulties to Develop the Thesis Using the Design Thinking Methodology
}

\author{
Diego Jesús Mamani Quispe \\ National University of San Agustín \\ Wilber Duilio Valverde Valverde \\ National University of San Agustín
}

Considering the problem of how to do the thesis at the National University of San Agustin de Arequipa in Peru (2019), the main difficulties of undergraduate and graduate students from the Faculty of Administration were explored through the design thinking methodology and possible solutions were analyzed. Using the semi-structured interview technique and following the stages of empathizing, defining, devising, prototyping and evaluating. We used tables and word cloud through Excel and the qualitative research software Nvivo for the results.

In the stage of empathizing, 10 graduates students were interviewed about their main difficulties. In the stage of ideation and prototype, a physical community was proposed through exchange activities between graduate students; discussing research topics according to research agenda and regarding the virtual community through social networks in order to interact with advisors, graduate and undergraduate students. In the evaluation stage as first feedback to 8 graduate students, they suggest applying a pilot test of the community and they see the idea as feasible.

Keywords: thesis, university research, student volunteering, virtual community, design thinking

\section{INTRODUCTION}

It is difficult for students to undertake the elaboration of the thesis, considering that they have to do research for this purpose. Linares (2002) says that "the very mention of the word research creates terror and panic in students, but because at the moment of suggesting them the elaboration of a preliminary research project or thesis is an extremely difficult task to understand and execute for the most part of the students" (p.129). The elaboration of the thesis should help the undergraduate or graduate student to create an interest in research and not the other way around. It should be an activity that is enjoyable (Rietveldt and Vara, 2012).

In the university census conducted by the National Institute of Statistics and Informatics (2013) to the question, "are you involved in a research group," and when selecting undergraduate students at the National University of San Agustín, forty-two percent (42\%) stated that they are part of a group. However, this fact has not had any positive effect on the students' thesis development. This is reflected in the thesis catalog of 
the Faculty of Administration's library, where an average of 8 students graduate each year through the thesis modality.

On the other hand, according to the new University Law No. 30220, which entered into force in El Peruano in 2014, graduate students are required to write a thesis for both the high school graduates and for the bachelor's degree. In this context there is a need to develop a research, so many students will have the difficulty to carry out this process.

And in light of this, several universities have been trying to solve the problem of doing the thesis such as Carlino's (2005) background in his research on "Why are theses not completed in graduate programs?" It is stated that "the lack of the thesis writer's time" also in the question how do they feel about doing the thesis, most of them are forced to do and feel jaded. Also Jose (2010) analyzes the main difficulties that arise when performing the thesis process in which he divides it into: inherent difficulties such as the fact that doing the thesis is not a gainful occupation and the fact that one is working; the environment and the editing of the text that in order to prepare the topic certain information is going to be considered.

And in light of this, several universities have been trying to solve the problem of doing the thesis; as the background of Carlino (2005) in his research on: "Why are theses not completed in graduate programs? In relation to this it is stated: "the lack of time of the thesis writer". In addition, in the question: "How do they feel about doing the thesis?" most of them are forced to do it and feel jaded. José (2010) also analyzes the main difficulties that arise when doing the thesis process, in which he divides it into: inherent difficulties, such as the fact that doing the thesis is not a remunerative activity and the fact that the student is working; the environment and the text modification, that in order to do the topic certain information must be considered.

It is up to the universities to improve the knowledge generation incentives. In order to achieve this, it is not only appropriate to focus on scientific and technological knowledge aimed at a sector linked to the competitive market, but also to solve the problems of an excluded majority. This also means research. On the other hand, Latin America is known for its low scientific production, despite the fact that research is one of the main roles of universities (Gascón, 2015).

This academic concern has led us to employ the design thinking methodology, which is according to Brown (2010) "an approach that uses the designer's sensitivity and problem-solving methods to meet people's needs in a technologically feasible and commercially viable way". Also including its advantages in interaction with the user, the search for finding a solution and deductive thinking as mentioned by Vianna, Adler, Lucena \& Russo (2016); and empathy as a characteristic to generate innovative solutions as stated by (Garcia, 2018).

This methodology, according to Kloeckner, De Souza and Duarte (2017) involves several phases or stages where different authors divide it into 3, such as Brown and Katz, IDEO, Jiao and Zhang. Similarly, Vianna et al. (2016) who explains it as immersion, ideation and prototyping. The authors Lewrick, Link and Leifer, (2018) indicate that in Japan it is grouped as: empathy, analysis, prototyping, and co-creation; others in 7 stages according to the author Goodspeed et al (what year?) although it has the core as argued by Ling, Chai and Yao (2015) of 3 worlds: "event, experiences and the products of the human mind in its abstract form." The key factor is the understanding of the needs and problems of the user in order to propose innovative solutions that involve the user, to see his/her acceptance, adaptation and, as indicated, creation goes hand in hand with the user who gives suggestions for constant improvement.

In the review of design thinking, it has been covered in the academic field as the example of Castillo and Gonzales (2016) from the International Congress of Technology and Innovation Management where based on the theme of "academic stress" sought to identify research questions from different perspectives. Also, the topic of the thesis development has been discussed in depth in the biomedical area in the research of Ramos and Sotomayor (2008). They also study the reasons for doing or not doing a thesis as detailed in the research of Arroyo, C. H., De la Cruz, W. y Miranda, U. E. (2008) which analyzes the difficulties for the development of undergraduate research.

In order to understand this problem: what have been the main difficulties in doing the thesis? The research was carried out using the Design Thinking methodology, where one of its objectives is to understand the problem and, according to its difficulties, a solution will be proposed following the steps 
included in this methodology. Afterwards, the solution was explored through the explanation by using slides where the part of the research results explains in greater detail the improvements and the acceptance of the interviewees.

Following this methodology, we proceeded to select ten graduate students and 5th year students from the different schools of the Faculty of Administration, whose results are shown in this article containing the following parts: the executive summary, abstract, introduction, results, discussion of the results, conclusions and bibliographical references.

Following the stages of design thinking, the author Brown (2010) explains the concepts to be applied:

a) Empathizing: The user is understood, using observation, getting involved with $\mathrm{him} / \mathrm{her}$.

b) Reflects on what has been learned from the user and according to its context.

c) Ideation: Concepts and resources for the prototype are delivered.

d) Prototyping: Drawings and items are developed in order to reach the final solution.

e) Evaluation: Feedback according to the opinions of users when testing the service, product.

Among the goals, there is the understanding of the difficulties of doing the thesis of undergraduate students, who graduated from the Faculty of Administration of the National University of San Agustín and as a hypothesis: among the main difficulty there is the selection of the thesis topic. As mentioned in the Baseline study of the UNSA (2016) that was done with the obtaining of a situational diagnosis of the activity in science, technology and technological innovation as a requirement for Active Science.

\section{METHODOLOGY}

The steps of the research answer these questions:

- What are the difficulties regarding doing the thesis? And, what would be an appropriate solution in undergraduate and graduate students in the Faculty of Administration in 2019? And what should be a proposed solution?

For this question it was focused on the stages of design thinking because of the direct contact with the person who suffers the need, that a suitable solution is looked for according to the need, and it will be adapted depending on his or her suggestions.

According to the established objective, the research adopts a qualitative approach within the classification of Hernandez, Fernandez and Collado (2014), and follows the design thinking methodology and the stages of: empathizing, defining, ideation, prototyping. The population of the study was targeted to graduate students from the Faculty of Administration by means of a non-probabilistic sampling.

TABLE 1

METHODOLOGICAL DESIGN OF THE RESEARCH

\begin{tabular}{|c|c|c|c|c|}
\hline \multicolumn{5}{|c|}{ Characteristics of the research } \\
\hline \multicolumn{5}{|c|}{ Qualitative-explorative } \\
\hline General objective & Specific objective & Phase & Technique & Tool \\
\hline \multirow{5}{*}{$\begin{array}{l}\text { To understand and propose } \\
\text { a solution to the } \\
\text { difficulties experienced } \\
\text { during thesis writing by } \\
\text { undergraduate students } \\
\text { and graduate students of } \\
\text { the Faculty of } \\
\text { Administration in } 2019 \text {. }\end{array}$} & $\begin{array}{l}\text { To identify the difficulties } \\
\text { in developing the thesis }\end{array}$ & Empathizing & Interview & Empathy map \\
\hline & $\begin{array}{l}\text { To understand the problem } \\
\text { concerning the difficulties } \\
\text { of writing a thesis. }\end{array}$ & Defining & Monitoring & Problem tree \\
\hline & \multirow{3}{*}{$\begin{array}{l}\text { To suggest a proposal to } \\
\text { reduce the difficulties in } \\
\text { carrying out the thesis. }\end{array}$} & Ideation & Annotations & Brainstorming \\
\hline & & Prototyping & Slides & Prototyping \\
\hline & & Evaluation & Interview & Prototype testing \\
\hline
\end{tabular}

Note: Prepared by the author. 


\section{Study Population}

For the development of the stages concerning the development of the thesis, it was decided to use nonprobabilistic sampling by criterion for the collection of graduate students. In the empathy stage, 10 students were interviewed, all graduates of the Faculty of Administration in 2019. For the prototype stage, 8 students were interviewed, of which five have participated in both stages. Those for the distance and time reasons did not agree to fill out the questions of the 2 nd interview.

\section{Stages Performed in the Problem-Solving Process}

Stage 1: Empathizing

For the development of the stage of understanding the difficulties of doing the thesis, a partially structured interview was used, which was conducted in a face-to-face and virtual manner. Ten students, who graduated from the Faculty of Administration between January 18, 2019 and February 8, 2019, were interviewed.

To understand the difficulties experienced in carrying out the thesis, the empathy tool was used, which is detailed in Table 1, both the elements for empathy and the interview questions.

TABLE 2

OPERATIONALIZATION OF DIFFICULTIES IN DOING THE THESIS FOR THE EMPATHY STAGE AND INTERVIEW QUESTIONS

\begin{tabular}{|c|c|c|}
\hline Variable & Dimensions & Items \\
\hline \multirow{9}{*}{$\begin{array}{c}\text { Difficulties in } \\
\text { writing a } \\
\text { thesis using } \\
\text { design } \\
\text { thinking }\end{array}$} & \multirow{4}{*}{ Facts } & $\begin{array}{l}\text { Regarding, the research problem you are thinking about for your } \\
\text { thesis, do you know how to solve it and why do you think so? }\end{array}$ \\
\hline & & What part of the thesis is the most difficult for you and why? \\
\hline & & $\begin{array}{l}\text { In the development of a thesis, which activity will take the most } \\
\text { time and resources, and why? }\end{array}$ \\
\hline & & $\begin{array}{l}\text { What has been your role (function) in developing a research } \\
\text { project and how was your experience? }\end{array}$ \\
\hline & Negative aspects & \multirow{2}{*}{$\begin{array}{l}\text { What do you think are the positive aspects and negative aspects } \\
\text { of doing research? }\end{array}$} \\
\hline & Positive aspects & \\
\hline & $\begin{array}{l}\text { Shortcuts or } \\
\text { informal solutions }\end{array}$ & $\begin{array}{l}\text { Do you know any specialists in each part of the thesis who can } \\
\text { help you during the development of the thesis? }\end{array}$ \\
\hline & Ideas & How would you solve the problem in order to do the thesis? \\
\hline & Cases & $\begin{array}{l}\text { Of your acquaintances or friends who did the thesis, where did } \\
\text { they have the most difficulty? }\end{array}$ \\
\hline
\end{tabular}

Note: Prepared by the author

Stage 2- Defining

The main difficulties encountered by students and graduate students during the thesis process were clarified.

\section{Stage 3- Ideating}

The brainstorming tool was used to search for solutions according to the theoretical and practical experience of the researchers.

Stage 4- Prototyping

Also in the fourth prototyping stage, the solution was created by using a paper in which it is shown through slides, and it is also explained by means of a video uploaded to YouTube. 
TABLE 3

ELEMENTS EVALUATED IN THE PROTOTYPE STAGE

\begin{tabular}{|l|l|l|}
\hline Variable & Dimensions & Items \\
\hline \multirow{5}{*}{$\begin{array}{l}\text { What do you think about } \\
\text { the solution? }\end{array}$} & What do you think about the solution that was explained? \\
\cline { 3 - 3 } & $\begin{array}{l}\text { Should this solution take place within the school where you } \\
\text { study, at the university or as a youth organization, and why? }\end{array}$ \\
\cline { 3 - 3 } & What strikes you most about what I have told you? \\
\cline { 3 - 3 } & \multirow{5}{*}{ Solution } & $\begin{array}{l}\text { Should this solution take place within the school where you } \\
\text { study, at the university or as a youth organization, and why? }\end{array}$ \\
\cline { 3 - 3 } & Would you be part of the community? \\
\cline { 3 - 3 } & $\begin{array}{l}\text { What do you think about the physical community to be } \\
\text { implemented? }\end{array}$ \\
\cline { 3 - 3 } & $\begin{array}{l}\text { What do you think about the development of the virtual } \\
\text { community? }\end{array}$ \\
\cline { 3 - 3 } & $\begin{array}{l}\text { From the directory of thesis advisors according to: topic, } \\
\text { data processing, APA rules. Would you pay for the service? }\end{array}$ \\
\cline { 3 - 3 } & What could be improved? & What else do you think is missing? \\
\hline & Solution ideas & Any questions or suggestions regarding the solution \\
\cline { 3 - 3 } & Additional questions & Have you listened to or been part of a similar idea? \\
\hline
\end{tabular}

Note: Prepared by the author

\section{Stage 5- Evaluating}

In order to evaluate their reaction, acceptance and proposal suggestions for the development of the thesis, eight individuals were interviewed, including undergraduate and graduate students from the Faculty of Administration, using paper documents as a tool to explain the solution according to Figures 2 and 3, using face-to-face and virtual interviews. Regarding the virtual part, first a URL of the YouTube video was sent and then the link corresponding to the virtual survey, which was developed with google form. At this stage it was developed during the first week of February 2019.

To obtain the results of the empathy stage of the interviews performed, Nvivo 11 qualitative research software was used to generate the word cloud in Figure 1 and the use of tables to show the results of the evaluation stage.

\section{RESULTS OF THE RESEARCH}

In the empathy stage, which comprises "understanding the user's needs and expectations" (Plattner, Meinel, and Leifer, 2011), the questions asked in the interview to the students and graduate students of the UNSA Faculty of Administration were: What difficulties do you have to do the thesis? to know their experience with their friends by asking them, how have your friends done in the thesis experience? And to know the expectation through the question: What is positive about doing a research?

\section{Test 1}

It was proposed as a hypothesis that the main difficulty that the students of the Faculty of Administration have to face is the research problem and it was thought that by means of a data base in which the theses are summarized up to that date. Progress was made on a topic, year and locations covered by the results, they did evaluate the idea solution. However, it was identified that the problem of developing the thesis involves more processes and a second interview was conducted to identify the difficulties that students have regarding the development of the thesis. 


\section{Test 2}

The questions comprising the interview were improved, the main questions being: what part of the thesis is the most difficult for you and why? With your colleagues or friends who did the thesis, what phase was most difficult for them? What do you think are the positive aspects and negative aspects of doing research? We also proceeded to collect general data such as gender, age, their status with the university, in order to identify whether they are students or graduate students, and the career they studied at the Faculty of Administration. In the first question, the most frequently repeated answer was the "problem statement" as indicated by the students and graduate students, and in the second question, what they had difficulty with was related to the results, both in conducting the surveys and analyzing the information.

In this second test, 10 students, graduated from the Faculty of Administration, were interviewed, being a non-probabilistic sample, considering that one of the objectives was to understand their difficulties, the sample was limited to that amount.

Table 4 summarized the information from the interviews based on the question What do you think are the positive aspects and negative aspects of conducting research? was filled in the positive and negative aspect part. The relevant data were filled in the Fact column of Table 4 and the Shortcuts section corresponds to how they have been solving to do the thesis or plan to solve it and the heading "Ideas" are the possible solutions suggested to do the thesis by the undergraduate and graduate students.

TABLE 4

\section{RESULTS OF INTERVIEWS CONDUCTED WITH UNDERGRADUATE AND GRADUATE STUDENTS TO UNDERSTAND THE DIFFICULTIES IN COMPLETING THE THESIS AT THE FACULTY OF ADMINISTRATION}

\begin{tabular}{|c|c|c|c|c|c|}
\hline Case & Fact & $\begin{array}{l}\text { Negative } \\
\text { aspect }\end{array}$ & $\begin{array}{c}\text { Positive } \\
\text { aspect }\end{array}$ & Shortcuts & Ideas \\
\hline $\begin{array}{l}\text { Banking and } \\
\text { Insurance } \\
\text { student, } 20 \\
\text { years old, } \\
\text { female, } \\
\text { undergraduate } \\
\text { student, } \\
\text { UNSA. }\end{array}$ & $\begin{array}{c}\text { She studies } 2 \\
\text { careers }\end{array}$ & Getting data & & $\begin{array}{l}\text { using secondary } \\
\text { sources }\end{array}$ & \\
\hline $\begin{array}{l}\text { Marketing } \\
\text { student, } 21 \\
\text { years old, } \\
\text { female, } \\
\text { undergraduate } \\
\text { student, } \\
\text { UNSA. }\end{array}$ & $\begin{array}{l}\text { Has defined } \\
\text { thesis topic }\end{array}$ & $\begin{array}{l}\text { Access to } \\
\text { information }\end{array}$ & & $\begin{array}{l}\text { Based on a } \\
\text { problem related to } \\
\text { the company } \\
\text { where she works }\end{array}$ & \\
\hline $\begin{array}{l}\text { Marketing } \\
\text { graduate, } 26 \\
\text { years old, } \\
\text { female, } \\
\text { UNSA. }\end{array}$ & & $\begin{array}{l}\text { Deciding on the } \\
\text { topic }\end{array}$ & $\begin{array}{l}\text { More or less } \\
\text { related to the } \\
\text { research } \\
\text { problem }\end{array}$ & & \\
\hline $\begin{array}{l}\text { Banking and } \\
\text { Insurance } \\
\text { student, } 21 \\
\text { years old, } \\
\text { female, }\end{array}$ & $\begin{array}{c}\text { She is in the first } \\
\text { positions }\end{array}$ & $\begin{array}{l}\text { Problem } \\
\text { statement }\end{array}$ & $\begin{array}{l}\text { To meet thesis } \\
\text { specialists }\end{array}$ & & $\begin{array}{c}\text { University } \\
\text { volunteering } \\
\text { that can } \\
\text { provide ideas }\end{array}$ \\
\hline
\end{tabular}




\begin{tabular}{|c|c|c|c|c|c|}
\hline $\begin{array}{l}\text { undergraduate } \\
\text { student, } \\
\text { UNSA. }\end{array}$ & & & & & $\begin{array}{l}\text { for thesis } \\
\text { work }\end{array}$ \\
\hline $\begin{array}{l}\text { Graduate, } 24 \\
\text { years old, } \\
\text { female, } \\
\text { UNSA. }\end{array}$ & $\begin{array}{c}\text { She had a thesis } \\
\text { advisor }\end{array}$ & $\begin{array}{l}\text { She does not } \\
\text { know } \\
\text { specialists for } \\
\text { each part of the } \\
\text { thesis }\end{array}$ & $\begin{array}{l}\text { She learns a } \\
\text { lot }\end{array}$ & $\begin{array}{l}\text { Problem } \\
\text { statement and } \\
\text { defining the } \\
\text { problem }\end{array}$ & \\
\hline $\begin{array}{l}\text { Graduate, } 26 \\
\text { years old, } \\
\text { female, } \\
\text { UNSA. }\end{array}$ & $\begin{array}{c}\text { She had a thesis } \\
\text { advisor }\end{array}$ & $\begin{array}{l}\text { Difficulty when } \\
\text { surveying }\end{array}$ & $\begin{array}{l}\text { Researching, } \\
\text { knowing, } \\
\text { learning }\end{array}$ & $\begin{array}{c}\text { Thesis was based } \\
\text { on her work } \\
\text { activity }\end{array}$ & \\
\hline $\begin{array}{l}\text { Banking } \\
\text { student, } 20 \\
\text { years old, } \\
\text { male, } \\
\text { undergraduate } \\
\text { student, } \\
\text { UNSA. }\end{array}$ & & $\begin{array}{l}\text { Difficulty in } \\
\text { defining the } \\
\text { problem, } \\
\text { hypothesis }\end{array}$ & $\begin{array}{l}\text { He meets } \\
\text { some thesis } \\
\text { specialists }\end{array}$ & & $\begin{array}{l}\text { University } \\
\text { volunteering } \\
\text { that can } \\
\text { provide ideas } \\
\text { for thesis } \\
\text { work }\end{array}$ \\
\hline $\begin{array}{l}\text { Marketing } \\
\text { student, } 22 \\
\text { years old, } \\
\text { male, } \\
\text { undergraduate } \\
\text { student, } \\
\text { UNSA. }\end{array}$ & & $\begin{array}{l}\text { Difficulty in } \\
\text { choosing } \\
\text { subject matter, } \\
\text { theoretical } \\
\text { framework }\end{array}$ & $\begin{array}{l}\text { He has some } \\
\text { research } \\
\text { proposals, he } \\
\text { knows } \\
\text { teachers }\end{array}$ & $\begin{array}{l}\text { Life experience } \\
\text { (visits to } \\
\text { companies, } \\
\text { congresses, } \\
\text { forums, etc.) }\end{array}$ & \\
\hline $\begin{array}{l}\text { Graduate, } 30 \\
\text { years old, } \\
\text { female, } \\
\text { Business } \\
\text { administration } \\
\text {, UNSA. }\end{array}$ & & $\begin{array}{l}\text { Difficulty with } \\
\text { the problem, } \\
\text { she does not } \\
\text { know } \\
\text { specialists }\end{array}$ & $\begin{array}{l}\text { Application of } \\
\text { previous } \\
\text { knowledge and } \\
\text { reinforcement } \\
\text { of practice. }\end{array}$ & $\begin{array}{c}\text { External } \\
\text { university advisor }\end{array}$ & $\begin{array}{l}\text { Acquiring in- } \\
\text { depth } \\
\text { knowledge; } \\
\text { being up to } \\
\text { date }\end{array}$ \\
\hline $\begin{array}{l}\text { Marketing } \\
\text { graduate, } 25 \\
\text { years old, } \\
\text { female, } \\
\text { UNSA. }\end{array}$ & & $\begin{array}{c}\text { Tools } \\
\text { development, } \\
\text { advisors for } \\
\text { each phase of } \\
\text { the thesis, time }\end{array}$ & $\begin{array}{c}\text { New } \\
\text { knowledge and } \\
\text { applying what } \\
\text { has been } \\
\text { learned }\end{array}$ & $\begin{array}{c}\text { To have a school } \\
\text { advisor }\end{array}$ & $\begin{array}{c}\text { Read, } \\
\text { research and } \\
\text { seek advisory } \\
\text { services }\end{array}$ \\
\hline
\end{tabular}

As can be seen in Table 1 of the 10 interviews conducted in the Faculty of Administration regarding the development of the thesis, the difficulties they have had (the negative aspects) are: defining a research problem, topic, advisor, obtaining information (theoretical framework, data). The positive side of doing a thesis is the application of knowledge, meeting specialists. In the ideas column concerning possible solutions, they indicated that the study area of the thesis should be where the student works, the assistance of an advisor, life experience, and the use of secondary sources. One of the proposals in order to solve these difficulties is that the university, through a volunteer program, could provide them with some ideas and look for an advisor. 
FIGURE 1

\section{WORD CLOUD FROM THE QUESTION WHAT PART OF THE THESIS IS THE MOST} DIFFICULT FOR YOU AND WHY? USING NVIVO 11 SOFTWARE

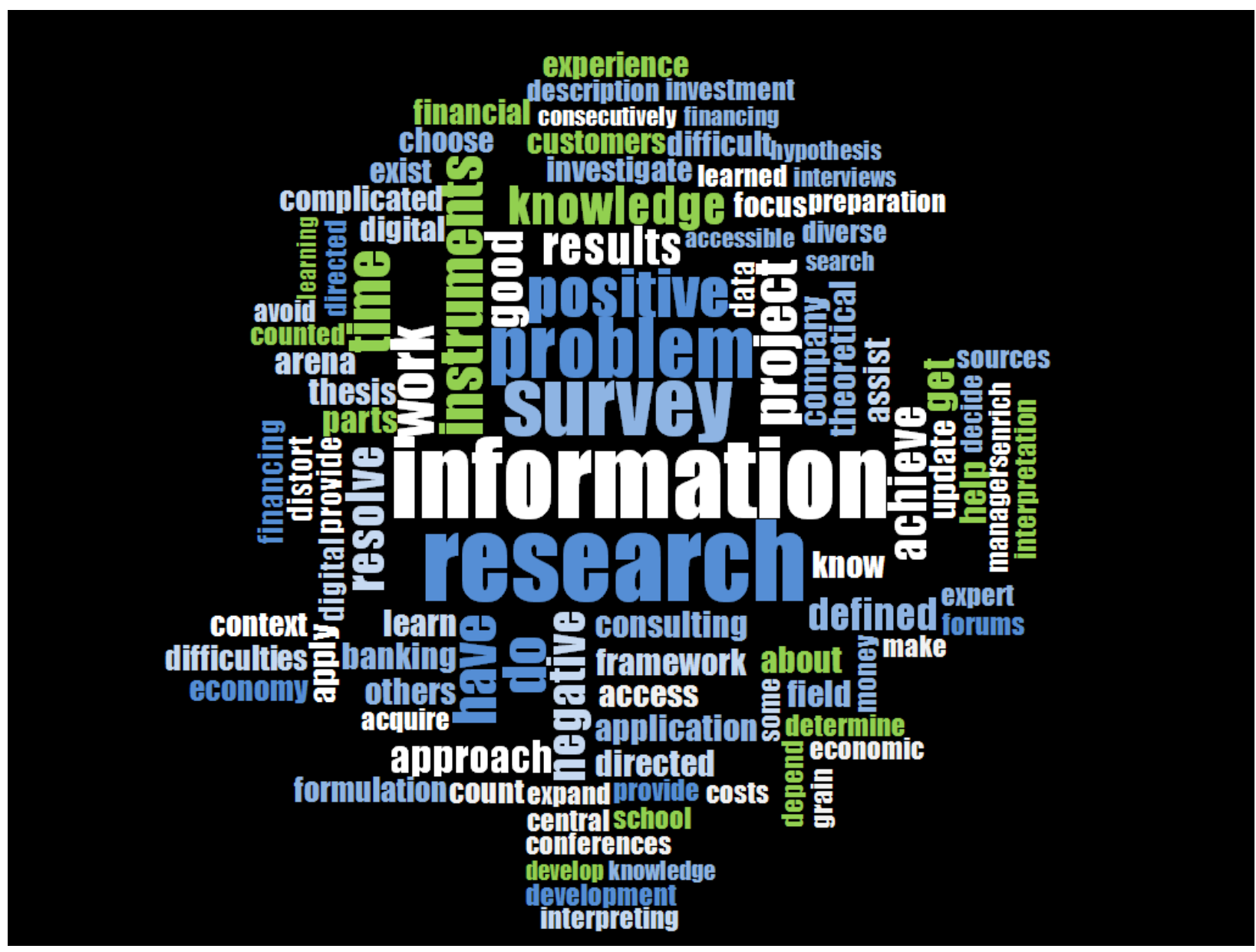

In Figure 1 according to the question what part of the thesis is the most difficult for you? the word cloud highlights information, survey and problem.

\section{Defining Stage}

In this stage "a viable and significant problem statement" is created as stated by (Plattner, n/d, p. 6) based on the elements of: "the clearly defined user, the user need and the insights obtained during the empathizing process" (Mejia, Montes, \& Rodriguez, 2016, p.8).

According to this stage, we proceeded to make this question: how to reduce these difficulties suffered by a graduate student from the Faculty of Administration? Considering that the elaboration of the thesis is a whole process in which there are basic problems. According to Table 4, such as: when making a problem statement, looking for specialists in the field, the fact that they work as pre-professional internships or in a job to obtain earnings, and that their school gives them the opportunity to apply what they have learned through volunteering.

\section{Ideation Stage}

In this stage according to the main difficulties that the graduate students of the Faculty of Administration have had/and are going to have, we proceeded to solve each of those difficulties that prevent 
to develop the thesis and create "a product and/or service that the customer considers valuable" (Ries, 2018, p.112).

The solution conceived is a "Co-Research Community" which is explained in Figures 2 and 3 below. At the prototype stage. This Co-Research Community will bring together members, advisors, undergraduate and graduate students for a research project.

\section{FIGURE 2 \\ PHYSICAL COMMUNITY ACTIVITIES}

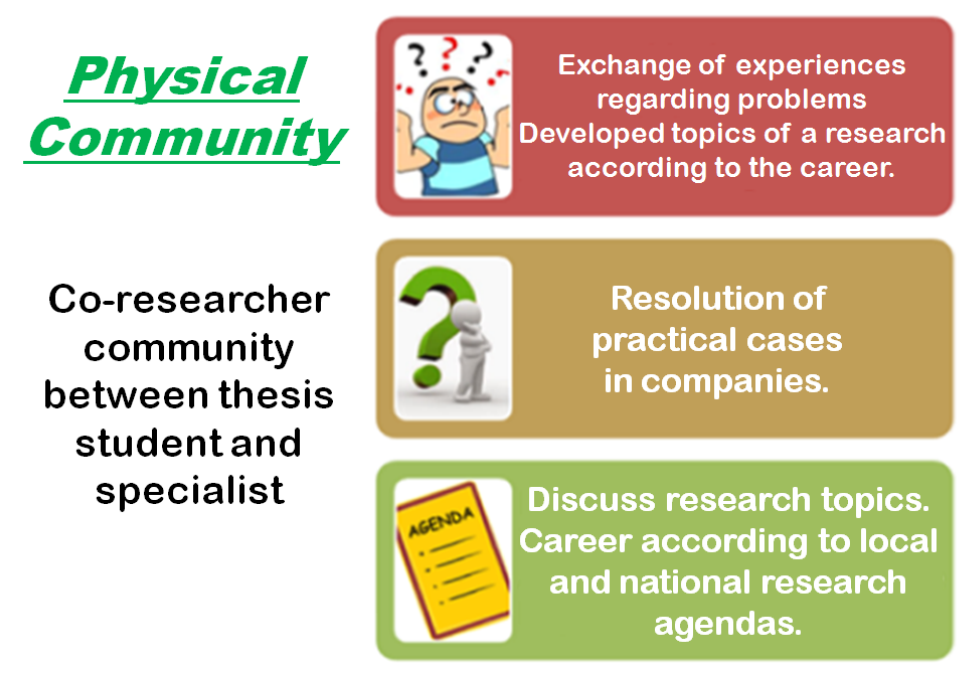

\section{Physical Community Activities}

In order to solve the main difficulties to elaborate the thesis that the graduate students of the Faculty of Administration of the National University of San Agustin experience, such as having a research problem, the topic; it was determined through the physical community activities in which they meet to exchange experiences in research topics according to the career. Also, by discussing topics according to research agendas, the student can explore a topic that is important for society and address problems in the different sectors, such as the research agendas that several institutions have, such as the Consortium for Social Economic Research, which is a partnership in which every year the annual research competition is developed and its Research Agenda is based on the topics prioritized by the Central Government, the fifteen research agendas of the book "Balance de Investigación en Políticas Públicas 2011 - 2016 y Agenda de Investigación 2017 - 2021" ("Balance of Public Policy Research 2011 - 2016 and Research Agenda 2017 - 2021") and 5 regions of Peru's country as provided in the CIES document (2018). In the case of Lima of the Pontifical Catholic University of Peru (2018) presented in August during the forum entitled "Agenda 2018: Urgent issues for regional and local development" proposals for regional authorities at the Peruvian level. At the Arequipa level, there is also the Arequipa Development Agenda, a document that was prepared with the goal of providing input to the governors of the region and development by the universities: National University of San Agustín, San Pablo Catholic University and University of Santa Maria and that among its topics are the regional problems from the social, economic, territorial and institutional point of view as indicated in (UCSP, 2015). and other documents that can be used as a guide that can be discussed among students and advisors if they have been developed as research, to develop proposals to be analyzed in a thesis.

Another of the activities of the physical community is to carry out practical business cases and thus reflect on their implementation using the scientific method by discussing their causes and solutions when meeting face-to-face. 
FIGURE 3

VIRTUAL COMMUNITY ACTIVITIES

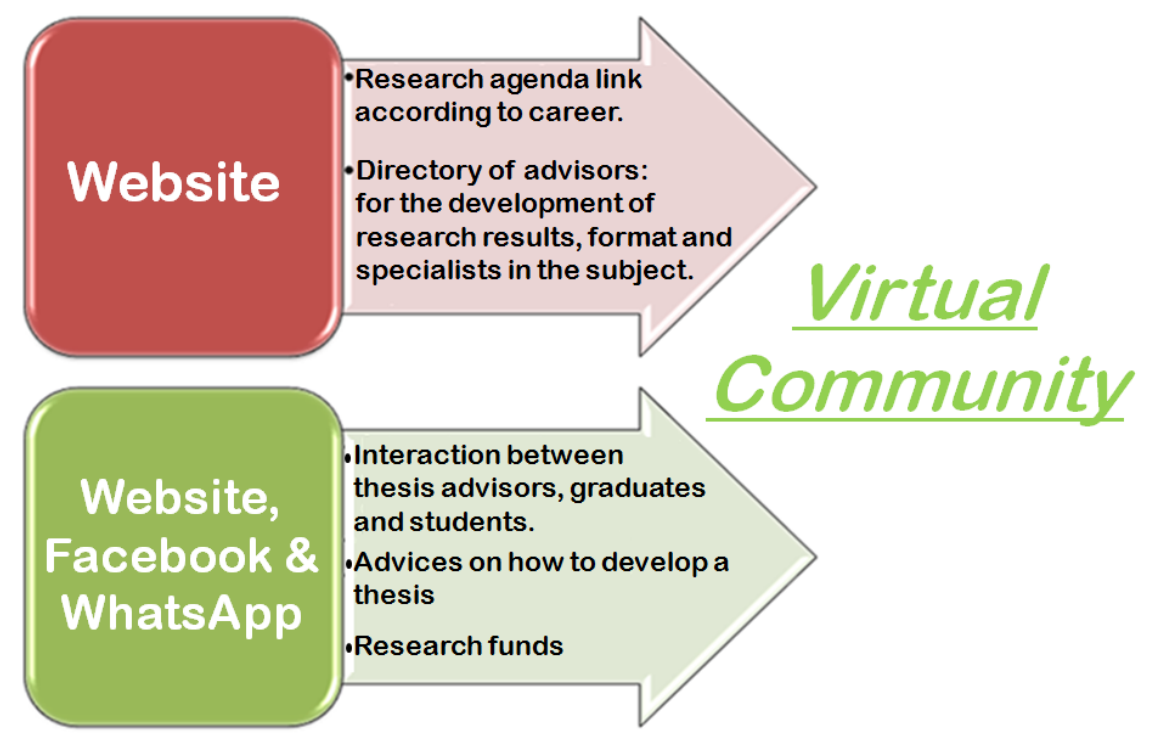

Virtual Community Activities

On the virtual side, we plan to have a website and a Facebook group. One of the activities is the the visualization of the research agendas of institutions that can contribute to the careers. Another activity is that advisors, undergraduate and graduate students can interact through the Facebook community and answer questions from students, feedback between them. To post information about the funds on the web page so that they can apply for them and serve as a reference on research topics.

The establishment of this community will contribute to the development of critical thinking for academic research (Alayza, Cortes, Hurtado, Mori, \& Tarnawiechi, 2015).

\section{In the Evaluation Stage}

We followed the recommendations of Castillo, Alvarez and Cabana (2014, p.304) about "service experience, perception and answering doubts regarding the design" of the co-research community based on slides showing the solution, we proceeded to interview 8 graduate students of the Faculty of Administration in order to assess the reaction and hear positive and negative opinions of this idea to reduce the difficulties to do the thesis.

\section{Results of the Physical and Virtual Community Demonstration}

Based on the question What do you think about the solution that was explained through the video? The most relevant of their responses were summarized in the second column of Table 3. Also when asked about whether this solution should be given: within the faculty you study at the university or as a youth organization and why? According to their answers, there is still some controversy as to whether it should be done inside or outside the university. Of those who agreed that it should be done inside the university, there were 3, the reasons being: that the topic of research is more developed, teachers are found and 2 said that it should be done as a youth organization, arguing that it would be more free and less bureaucratic and among other reasons was because they were graduates, the others were indifferent, whether inside or outside the university campus and did not give their opinion.

And in the question From the proposals of the physical and virtual community, What strikes you the most? They expressed their interest in having specialists in different topics, regarding the physical community part, getting a network of contacts and receiving the experience of those who have already done research. 
When asked about the virtual community, what do you think would help the most as a complement to the physical community in order to agree on schedules and indicated that it is a good option? And in the case of the physical community, they suggest to agree on the schedule and think that it is important for the community to contribute with research.

Under the question Have you heard or been part of a similar idea?, three interviewees have never heard a similar idea before, one stated that "in Colombia there is a similar idea and as a similar idea you are part of some Facebook groups that share research and you have heard through social networks, but they are for private sectors that help you solve the thesis and are obviously paid". Showing that the idea as a community is novel and that the thesis advisory activity is an idea that in some ways is similar to others, but as a private entity.

TABLE 5

SYSTEMATIZATION OF THE INTERVIEWS RESULTS BY SHOWING SLIDES

\begin{tabular}{|c|c|c|c|}
\hline Case & $\begin{array}{l}\text { What do you think } \\
\text { about the solution? }\end{array}$ & $\begin{array}{l}\text { What would } \\
\text { it work? }\end{array}$ & Suggestions for improvement \\
\hline $\begin{array}{l}\text { Banking student, } 20 \text { years } \\
\text { old, male, UNSA, 5th year }\end{array}$ & Feasible & $\begin{array}{l}\text { Feasible in } \\
\text { the virtual } \\
\text { part }\end{array}$ & $\begin{array}{l}\text { Coordinating with universities, } \\
\text { regional government, virtual } \\
\text { lectures }\end{array}$ \\
\hline $\begin{array}{l}\text { Banking student, } 20 \text { years } \\
\text { old, female, UNSA, 5th year }\end{array}$ & The ideas can flow & She agrees & Developing the virtual part \\
\hline $\begin{array}{l}\text { Marketing graduate, } 21 \\
\text { years old, male, UNSA. }\end{array}$ & Interesting & Yes & $\begin{array}{l}\text { Define what kind of people are } \\
\text { looking for }\end{array}$ \\
\hline $\begin{array}{l}\text { Marketing graduate, } 26 \\
\text { years old, female, UNSA. }\end{array}$ & Interesting & Yes & Technology \\
\hline $\begin{array}{l}\text { Banking student, } 20 \text { years } \\
\text { old, male, UNSA, } 5 \text { th year }\end{array}$ & $\begin{array}{l}\text { It would help me to } \\
\text { get contacts }\end{array}$ & Yes & $\begin{array}{l}\text { To start with a pilot test, to bring } \\
\text { together other universities as } \\
\text { well }\end{array}$ \\
\hline $\begin{array}{l}\text { Marketing student, } 21 \text { years } \\
\text { old, male, UNSA. }\end{array}$ & $\begin{array}{l}\text { It would help me in } \\
\text { achieving my research } \\
\text { problem }\end{array}$ & Very feasible & Customized workshops \\
\hline $\begin{array}{l}\text { Marketing graduate, } 21 \\
\text { years old, female, UNSA. }\end{array}$ & Ideas on having topics & & $\begin{array}{l}\text { That everything is followed as } \\
\text { explained }\end{array}$ \\
\hline $\begin{array}{l}\text { Banking student, } 21 \text { years } \\
\text { old, female, UNSA, } 5 \text { th year }\end{array}$ & $\begin{array}{l}\text { Physical community, it } \\
\text { is interesting for } \\
\text { sharing experiences. }\end{array}$ & & $\begin{array}{l}\text { That it be a nexus of both the } \\
\text { physical and virtual community. }\end{array}$ \\
\hline
\end{tabular}

Note: Results of the interview with undergraduate and graduate students of the Faculty of Administration using the slides.

In the stage of explaining the solution shown in Table 5, undergraduate and graduate students think that the solution is feasible and interesting. Suggestions include coordinating with universities, emphasizing the use of social networks for the virtual community and starting with a pilot test to collect improvements.

At this stage of being feasible it is no longer necessary to make a disruption (change) as mentioned by Pressman (2018) to the solution, but once the community program is applied, it will be improved and unnecessary activities will be removed according to the experiences of the members.

\section{DISCUSSION OF RESULTS}

As the main difficulty of the thesis is the fact of stating the research problem, the funnel method proposed by Vara (2012) in his text "7 steps for a successful thesis" can be considered for its formulation, 
which is based on going from general to particular premises. Also as Quivy and Van (1988) state that the research question must be clear, achievable and relevant.

As explained in the ideation results, the development of a physical and virtual community does not solve how to state a research problem, but it does provide alternatives for research problems, deepen topics and provide feedback to the student through the experiences of graduate students and advisors, both in person and virtually.

In the conclusion to solve the difficulties of doing the thesis that resulted in: problem statement, methodology, the creation of a physical and virtual community was proposed. As a virtual community it would contribute in terms of speed and is more optimal in the communication between a thesis student and the advisor, as Ramírez \& Amaro's (2013) mentioned in their research that "there is collaboration among its members".

Also in addition to an advisory board for the thesis process that is proposed with activity in both the physical and virtual community shown in Figure 2 and 3 it is proposed to contribute to the formal errors that occur when doing the thesis as mentioned by Arias (2006, p.61) as: "citing authors that do not correspond to the bibliography, incorrect use of formal language" these are activities that can be delegated to someone experienced and give priority to errors of substance and it would be advisable to consider the experience of the University of Florida that through the Tutor Matching Service software allows the student to search for academic tutors as mentioned in the text "Comunicación e industrial digital "(Universidad de Lima, 2014) ("Communication and digital industrial" (University of Lima, 2014))

In the case of the undergraduate students of the Faculty of Administration, the main difficulty is to state the problem and to have a topic, compared with the study of Carlino (2005), which focuses on a group of postgraduate master's degree students who reported that the lack of time is mostly due to the fact of working, having a family and having more responsibilities, compared with the undergraduate stage, where they still have more time, but there is a deficiency in knowledge.

And according to time being a factor that makes it difficult to do the thesis, it can be considered that in this virtual community graduate students participate, being necessary to be checked in a following study.

Ten people were interviewed in the exploration stage and eight were used in the prototype demonstration, five of them have participated in both stages and the others, for reasons of distance and time, did not agree to fill out the questions in the second interview.

The development of a co-research community also contributes to the student's "integration and development of research conduct" (Arroyo \& De La Cruz and Miranda, 2008, p.448) and the development of a more critical problem-solving capacity.

In a next stage, when using the co-research community through a pilot test, it is necessary to evaluate if the thesis advisors can interact with the virtual side because the Baby Boomers, generation born between 1940 and 1960, as classified by Howe and Straus (2007) and very few have adopted to this technological change and could be better coordinated with the generation Y, the Millenials, born between 1980 and 2000.

On the solution side, a co-research community is proposed and on the virtual community side, as a background, Avila, Miranda and Echevarría (2009) analyze the communication tools used between 2 institutional research teams and an academic community through virtual platforms, gives us a first advance of how this idea has gone when using ICT as a tool. And as the author states, there is a weak digital culture that should be considered when starting this community, and he also highlights that technological tools are a priority for pedagogical use (Perrazo, 2008).

It is necessary to provide emphasis to the part of the digital community as indicated by the suggestion in Table 2 of the interviewees, since as indicated by the pollster Datum (2017) in Peru, 99\% of millennials use Facebook, $81 \%$ Youtube, $42 \%$ prefer Instagram and 25\% use Twitter and undergraduate and graduate students belong to this generation and can take advantage of this means of communication.

The activity regarding the review of research agendas of institutions encourages students to learn about priority topics by sector and contributes to what Osada, Ruiz and Ramos (2010, p.306) suggest "that a link is formed between the student and the institution, whether formal or informal".

Also in the activity of sharing experiences of graduate students, there is an acceptance by the interviewees. Although in the opening of the co-research community it is necessary to evaluate their 
participation, if it is going to be in person they will have to come on a weekend and taking into account their schedules and the possibility of not coinciding with their work; or if it is feasible for the virtual side, consider that the graduate's link with the university is already disconnected from that environment and it would be difficult to contact them.

For a next study it would be advisable to evaluate the application of the digital community through a web page and that the students use it to evaluate their reaction, if it contributes to the development of the thesis and to test the improvements according to their opinions. Also if this solution can be implemented as a strategy within the faculties of the university after coordination with the vice-rectorate of research or externally as a private entity that monitors its execution.

\section{CONCLUSIONS}

In relation to the main objective of the difficulties in doing the thesis, it has been possible to highlight, according to Figure 1 of the word cloud, the statement of the research problem, topic and theoretical framework are the main problems of the 5th year student, graduates of the Faculty of Administration of the National University of San Agustín being one of the difficulties that is consistent with the hypothesis stated when choosing the topic according to the 2016 Baseline study conducted by the said university.

Next, the stages of the design thinking methodology, in the empathy stage the difficulties were identified: problem statement, topic, theoretical framework and according to the results in the stage of defining the use of social networks was evaluated, which in the different schools of the Faculty of Administration of the National University of San Agustín suffer the same difficulties.

Then, in the ideation stage, the main concepts were identified, these were student interaction, communication with the advisor; having a problem to research.

In the prototype stage, the proposed solution has been developed in the stages of ideation, prototype is intended to be more efficient during the process of the undergraduate thesis from the problem statement to the same substantiation, giving priority to the errors of substance and formal errors of the thesis that can be delegated.

Finally, in the evaluation stage, when this solution is shown and explained through slides to undergraduate and graduate students, there is an acceptance, they are interested in this proposal because they can study a topic in depth, have a specific topic and the suggestions of the proposal are to optimize the use of social networks, coordinate with universities and start with a pilot test.

\section{ACKNOWLEDGEMENT}

We thank the undergraduate and graduate students of the Faculty of Administration of the National University of San Agustín for their time availability during the interviews.

Translated \& edited by American Publishing Services (https://americanpublishingservices.com/).

\section{REFERENCES}

Alayza, C., Cortes, G., Hurtado, G., Mori, E., \& Tarnawiechi, N. (2015). Iniciarse en la investigación académica. Lima, Perú: Universidad Peruana de Ciencias Aplicadas.

Arroyo, C., De la Cruz, W., \& Miranda, U.E. (2008, April). Dificultades para el desarrollo de investigaciones en pregrado en una universidad pública de provincia, Perú. Revista Peruana de Medicina Experimental y Salud Publica, 25(4). Retrieved from http://www.scielo.org.pe/scielo.php?script=sci_arttext\&pid=S1726$46342008000400021 \& \operatorname{lng}=\mathrm{es} \& \operatorname{lng}=\mathrm{es}$

Arias, F. (2006). Mitos y errores en la elaboración de tesis \& Proyectos de investigación. Caracas, Venezuela: Editorial Episteme. 
Ávila, L., Miranda, A., \& Echevarría, M. (2009, March). Construcción de comunidades virtuales para la investigación. Revista de Universidad y Sociedad Del Conocimiento, 6(1). Retrieved from https://www.researchgate.net/publication/28264389

Brown, T. (2010). IDEO. Retrieved January 5, 2016, from https://www.ideo.com/about/

Carlino, P. (2005, October). ¿Por qué no se completan las tesis en los postgrados? Obstáculos percibidos por maestrandos en curso y magistri exitosos. Educere, 9(30), 415-420.

Castillo, M., Álvarez, A., \& Cabana, R. (2014, September). Design thinking: Como guiar a estudiantes, emprendedores y empresarios en su aplicación. Redalyc, $X X X V(3)$. Retrieved from http://www.redalyc.org/articulo.oa?id=360433598006

Castillo, R., \& González, D. (2016, October). Design Thinking Aplicado a Procesos De Investigación Cualitativa. Experiencia Con Una Tesis Doctoral. Retrieved from https://www.researchgate.net/publication/309566644

CIES. (2018). Anexo 1: Agenda de investigación. Retrieved from http://www.cies.org.pe/sites/default/files/seminarioanual/anexo_1_agenda_de_investigacion_1.pdf

Datum. (2017). ¿En qué se diferencian los millenials del Perú? Retrieved from https://www.datum.com.pe/new_web_files/files/pdf/Millennials.pdf

García, A. (2018). La metodología Design Thinking: Revolución en los negocios.

Gascón, Y. (2008, July-December). El síndrome de todo menos tesis "TMT" como factor influyente en la labor investigativa. Copérnico, $V(9)$. Retrieved from $\mathrm{http} / / /$ copernico.uneg.edu.ve/numeros/c09/c09_art05.pdf

Gestión. (n.d.). Design thinking: Revisando casos. Retrieved from https://gestion.pe/blog/innovar-o-sercambiado/2018/11/design-thinking-revisando-casos.html

Hernández, R., Fernández, R., \& Collado, B. (2014). Metodología de la investigación. México, México: Editorial McGraw-Hill.

Howe, N., \& Strauss, W. (2000). Millennials Rising: The Next Great Generation. Nueva York, EEUU: Vintage Books.

Instituto Nacional de Estadística e Informática. (2011). Censo Nacional Universitario 2010. Lima, Perú: INEI

José, F. (2010, May-August). Elaboración de tesis: La crisis necesaria. Humanidades Médicas, 10(2). Retrieved from http://scielo.sld.cu/scielo.php?script=sci_arttext\&pid=S1727$81202010000200012 \& \operatorname{lng}=\mathrm{es} \&$ tlng=es

Kloeckner, A., De Souza, C., \& Duarte, J. (2017, September). Design thinking methods and techniques in design education. International conference on engineering and product design education. Retrieved from https://www.designsociety.org/publication/40369/DESIGN+THINKING+METHODS+AND+TE CHNIQUES+IN+DESIGN+EDUCATION

La Republica. (2017, December 6). Facebook, Instagram o Twitter: ¿Qué red social usan más los millennials en Perú? Retrieved from https://larepublica.pe/tendencias/1154603-facebookinstagram-o-twitter-que-red-social-usan-mas-los-millennials-en-peru

Lewrick, M., Link, P., \& Leifer, L. (2018). The Design Thinking Playbook: Mindful Digital Transformation of Teams, Products, Services, Businesses and Ecosystems. Canada: Verlag Vahlen $\mathrm{GmbH}$, München.

Ley N 30220. Ley universitaria. Congreso de la Republica. (2014). Retrieved from https:/www.sunedu.gob.pe/wp-content/uploads/2017/04/Ley-universitaria-30220.pdf

Ling, J., Chai, Ch., \& Yao, H. (2015). Design thinking for education. Nueva York, EE. UU: Editorial Springer.

Linares, R. (2002). Maestría, investigación y tesis: ¿Reto o dificultad a vencer? Geoenseñanza, 7(1-2). Retrieved from https://www.redalyc.org/pdf/360/36070212.pdf

Mejía, C., Montes, C., \& Rodríguez, P. (2016). Propuesta de solución educativa con soporte tecnológico para prevenir las lesiones en niños de 4 y 6 años de Lima Metropolitana mediante la 
metodología Design thinking y lean startup (Tesis de pregrado). Retrieved from $\mathrm{http}: / /$ tesis.pucp.edu.pe/repositorio/handle/123456789/8449

Osada, J., Ruiz P., \& Ramos, M. (2010). Estudiantes de pregrado: el futuro de la investigación. Revista Peruana de Medicina Experimental y Salud Publica, 27(2), 305-306. Retrieved April 25, 2019, from http://www.scielo.org.pe/scielo.php?script=sci_arttext\&pid=S1726$46342010000200027 \& \operatorname{lng}=\mathrm{es} \& \operatorname{lng}=\mathrm{es}$

Perazzo, M. (2008). La ruta de la alfabetización digital en la educación superior: Una trama de subjetividades y prácticas. RUSC. Universities and Knowledge Society Journal, 5(1), 1-10.

Plattner, H. (n.d.). Mini guía: Una introducción al Design Thinking. Stanford.

Plattner, H., Meinel, C., \& Leifer, L. (2011). Design Thinking: Understand-Improve-Apply. Berlin: Springer Verlag.

Pressman, A. (2018). Design Thinking: A Guide to Creative Problem Solving for Everyone. New York, EEUU: Routledge.

Quivy, R., \& Van Campenhoudt, L. (1988). Manuel de recherche en sciences sociales. Paris, Francia: Dunod.

Ramírez, D., \& Amaro, J. (2013, April). Comunidades virtuales, nuevos ambientes mismas inquietudes: el caso de Taringa! Revista Latinoamericana, 12(34). Retrieved from https://dialnet.unirioja.es/servlet/articulo?codigo $=5751668$

Ramos, M., \& Sotomayor, R. (2008). Realizar o no una tesis: Razones de estudiantes de medicina de una universidad pública y factores asociados. Revista Peruana de Medicina Experimental y Salud Pública, 25(3), 322-324.

Ries, E. (2018). El método Lean Startup. Lima, Perú: Editorial Planeta Perú S.A.

Rietveldt, F., \& Vera, L. (2012, May-August). Factores que influyen en el proceso de elaboración de la tesis de grado. Omnia, 18(2). Retrieved from https://www.redalyc.org/pdf/737/73723402008.pdf

Universidad de Lima. (2014). Comunicación e industria digital. Lima, Perú: Fondo Editorial.

UNSA. (2016). Estudio de Linea de Base. Retrieved from http://vri.unsa.edu.pe//wpcontent/uploads/2017/01/ESTUDIO-DE-L\%C3\%8DNEA-DE-BASE-FINAL.pdf

UCSP. (2015). Agenda-para-el-Desarrollo-de-Arequipa-2015-2018-final. Retrieved from http://ucsp.edu.pe/wp-content/uploads/2017/03/Agenda-para-el-Desarrollo-de-Arequipa-20152018-final.pdf

Vara, A. (2012). 7 Pasos para una tesis exitosa. Lima, Perú: Universidad San Martin de Porres

Vianna, M., Viannna, Y., Adler, I., Lucena, B., \& Russo, B. (2016). Design Thinking en los negocios. Rio de Janeiro, Brasil: Editorial MJV Tecnología. 